\title{
Pengaruh Financing to Deposit Ratio (FDR), Dana Pihak Ketiga (DPK) dan Return On Asset (ROA) Terhadap Pembiayaan Musyarakah (Studi Kasus Bank Syariah Mandiri Periode 2010-2018)
}

\author{
Sumadi $^{1)}$, A. Haris Romdhoni ${ }^{2)}$ \\ ${ }^{1,2}$ Institut Teknologi Bisnis AAS Indonesia \\ *Email korespondensi: ahmadsumadi1924@gmail.com
}

\begin{abstract}
Abstrak
Penelitian ini bertujuan untuk mengetahui pengaruh Financing To Deposit Ratio (FDR), Dana Pihak Ketiga (DPK) dan Return On Asset (ROA) terhadap pembiayaan musyarakah pada Bank Syariah Mandiri (BSM) dari tahun 2010-2018 baik secara parsial maupun simultan. Populasi dalam penelitian ini adalah perbankan syariah yaitu Bank Syariah Mandiri (BSM) tahun 2010-2018 sebanyak 32 diambil secara purposive sampling. Data yang digunakan menggunakan data sekuder yang diperoleh dari laporan keuangan triwulan Bank Syariah Mandiri (BSM). Metode yang digunakan penelitian ini adalah dengan menggunakan metode uji asumsi klasik dimana uji Asumsi Klasik ini terdiri dari empat uji yaitu uji Normalitas, uji Multikolinieritas, uji Heterokedastisitas dan uji Autokorelasi selain menggunakan uji Asumsi Klasik, dalam penelitian ini juga menggunakan uji dengan analisis data dari analisis regresi linier berganda serta menggunakan uji $t$ atau uji parsial dan uji $\mathrm{F}$ atau uji secara simultan maupun bersama-sama. Pada penelitian menggunakan jenis data yang bersifat kuantitatif. Hasil penelitian menunjukkan bahwa variabel yang berpengaruh terhadap pembiayaan musyarakah adalah variabel Financing To Deposit Ratio (FDR) dengan nilai $P$-value sebesar 0,000 dimana nilai ini lebih besar dari 0,05 dan nilai thitung sebesar -4,916 dimana nilai ini lebih besar dari nilai tabel yaitu 2,0484 dan Dana Pihak Ketiga dengan nilai P-value sebesar 0,000 dimana nilai ini lebih besar dari 0,05 dan nilai $t_{\text {hitung }}$ sebesar 4,559 lebih besar dari nilai tabel yaitu 2,0484 sedangkan variabel yang tidak berpengaruh terhadap pembiayaan musyarakah adalah variabel Return On Asset (ROA) dengan nilai P-value 0,428 dimana nilai ini lebih besar dari 0,05 dan $\mathrm{t}_{\text {hitung }}$ lebih kecil dari $\mathrm{t}_{\text {tabel }}$ dimana nilai $t_{\text {hitung }}$ sebesar 0,805 dan nilai $t_{\text {tabel }}$ sebesar 2,0484. Secara simultan seluruh variabel yaitu FDR, DPK dan ROA secara bersama-sama berpengaruh terhadap pembiayaan musyarakah pada Bank Syariah Mandiri (BSM) tahun 2010-2018 dengan nilai signifikansinya sebesar 0,000 dimana nilai sig tersebut lebih kecil dari 0,05 sedangkan nilai $\mathrm{F}_{\text {hitung }}$ lebih besar dari nilai $\mathrm{F}_{\text {tabel }}$ dimana nilai $\mathrm{F}_{\text {hitung }}$ sebesar 25,160 sedangkan nilai $\mathrm{F}_{\text {tabel }}$ sebesar 2.95 .
\end{abstract}

Kata kunci: Financing To Deposit Ratio (FDR), Dana Pihak Ketiga (DPK), Return On Asset (ROA), musyarakah

\section{Abstract}

This study aims to determine the effect of Financing To Deposit Ratio (FDR), Third Party Fund (DPK) and Return On Assets (ROA) on Musyarakah financing at Bank Syariah Mandiri (BSM) from 2010-2018 either partially or simultaneously. Population in this research is syariah banking that is Bank Syariah Mandiri (BSM) year 20102018 as many as 32 taken by purposive sampling. Data used using sekuder data obtained from quarterly financial report of Bank Syariah Mandiri (BSM). The method used in this research is using the classical assumption test method where the Classic Assumption test consists of four tests namely Normality test, Multicolinierity test, Heterocedasticity test and Autocorrelation test in addition to using Classic Assumption test, in this study also used the test with data analysis from analysis multiple linear regression and using $t$ test or partial test and $F$ test or test simultaneously or together. In the study using the type of data that is quantitative. The result of this research shows that the variable that influences the musyarakah financing is the Financing To Deposit Ratio (FDR) variable with $P$-value value of 0,000 which is bigger than 0,05 and the value of $t$-count is -4,916 where this value is bigger than ttable 2.0484 and Third Party Funds with a value of $P$-value of 0,000 where this value is greater than 0.05 and tcount value of 4.559 is greater than the value of ttable is 2.0484 while the variable that does not affect the musyarakah financing is the variable Return On Asset (ROA) with a value of P-value 0.428 where this value is greater than 0.05 and $t$ count is smaller than ttable where the tcount value is 0.805 and the value of ttable is 2.0484. Simultaneously all variables that are FDR, DPK and ROA together effect on musyarakah financing at Bank Syariah Mandiri (BSM) year 2010-2017 with a significance value of 0,000 where the value of sig is smaller 
than 0.05 while the value of Fcount is greater than Ftable value where the value of Fcount equal to 25,160 while Ftable value equal to 2.95 .

Keywords: Financing To Deposit Ratio (FDR), Third Party Fund (DPK), Return On Assets (ROA), musharaka.

Saran sitasi: Sumadi., Romdhoni., A. H., \& Nanda, F. W. A. (2020). Pengaruh Financing to Deposit Ratio (FDR), Dana Pihak Ketiga (DPK) dan Return On Asset (ROA) Terhadap Pembiayaan Musyarakah (Studi Kasus Bank Syariah Mandiri Periode 2010-2018). Jurnal Ilmiah Ekonomi Islam, 6(03), 598-608. doi:http://dx.doi.org/10.29040/jiei.v6i3.1430

DOI: http://dx.doi.org/10.29040/jiei.v6i3.1430

\section{PENDAHULUAN}

Perbankan syariah merupakan suatu badan ataupun lembaga keuangan yang prinsip-prinsipnya menggunakan prinsip dengan berbasis syariah. Hal ini berbeda dengan perbankan konvensional yang hanya mengutamakan prinsip keuntungan saja. Perkembangan perbankan syariah mengalami perkembangan yang sangat pesat dibandingkan dengan perbankan konvensional. Banyak nasabah yang sudah menggunakan produk-produk perbankan syariah namun ada yang masih menggunakan perbankan konvensional.

Seiring dengan berkembangnya perbankan syariah, produk- produk yang ditawarkan kepada calon nasabah juga tidak kalah bagus dengan produkproduk konvensional, dimana produk perbankan syariah yang ditawarkan pada nasabah adalah dalam bentuk bagi hasil seperti musyarakah dan mudharabah serta dalam bentuk jual beli seperti murabahah. Bagi hasil merupakan salah satu alternatif dalam menetukan keuntungan bagi nasabah dan perusahaan serta mempunyai perbedaan dibandingkan dengan bunga atau yang mengandung riba (Liliani dan Khairunnisa, 2015).

Pada produk perbankan syariah mempunyai tujuan yaitu untuk mengutamakan kesejahteraan masyarakat dan membantu taraf hidup perekonomian masyarakat. Produk yang ditawarkan kepada nasabah tidak hanya berupa mudharabah, musyarakah maupun murabahah saja tetapi terdapat produk lain seperti pinjaman qardh, wa'diah atau berupa titipan dan produk yang berupa ijarah, dari beberapa produk perbankan syariah juga terdapat kelemahan serta kelebihan dari masing-masing produk tersebut.

Bank syariah menawarkan pembiayaan berdasarkan jual beli (ba'i), sewa beli (ijarah waiqtina), bagi hasil (syirkah) serta pembiayaan lainnya. Pada bank syariah yang sering dimanfaatkan oleh para pelaku usaha adalah pembiayaan yang berupa produk murabahah dan produk mudharabah, dari kedua produk tersebut bertujuan untuk membeli alat dan barang serta untuk modal kerja. Pembiayaan yang ditawarkan kepada nasabah tidak hanya pembiayaan yang disebutkan diatas tetapi banyak pembiayaan-pembiayaan lainnya dengan harapan menjadi solusi perekonomian saat ini (Suhardjono, 2003).

Fakta yang terjadi pada pembiayaan antara mudharabah, musyarakah maupun murabahah yang paling mendominasi adalah pembiayaan murabahah atau jual beli selanjutnya diikuti dengan pembiayaan mudharabah dan pembiayaan musyarakah atau dengan bagi hasil hal ini mengakibatkan tidak optimalnya sistem bagi hasil (Annisa dan Dedi, 2017), sehingga tidak mencerminkan sistem prinsip perbankan syariah yaitu bagi hasil jika murabahah yang paling diunggulkan.

Alternatif untuk mengatasi masalah ini seharusnya lembaga keuangan baik perbankan maupun lembaga keuangan lainnya yang berbasis syariah harus mengoptimalkan prinsip bagi hasilnya dan akad yang dilakukan harus sesuai dengan pembiayaan yang pilih oleh nasabah. Misalnya saja pada pembiayaan mudharabah dan musyarakah akad yang dilakukan juga harus sesuai dengan produk pembiayaan yaitu bagi hasil, jika nasabah ingin jual beli nasabah memilih produk pembiayaan murabahah dan akad yang dilakukan juga harus sesuai dengan produk yang dipilih.

Perbankan juga harus memberikan pengetahuan kepada masyarakat tentang produk yang ditawarkan dan menjelaskan tentang perbedaan produk pembiayaan mudharabah, musyarakah maupun murabahah. Hal ini bertujuan agar nasabah dapat memilih pembiayaan sesuai dengan keinginan nasabah.

Fakta yang terjadi pada pembiayaan yang ditawarkan kepada nasabah kemudian nasabah tertarik 
akan produk pembiayaan dan melakukan pembiayaan tersebut tidak selalu berjalan lancar, terdapat faktorfaktor yang mempengaruhi pembiayaan baik pada perbankan maupun pada lembaga keuangan lainnya (Umiyati dan Leni, 2017).

Faktor-faktor yang mempengaruhi pembiayaan pada bank syariah terbagi menjadi dua yaitu faktor internal dan faktor eksternal. Faktor internal merupakan salah satu faktor yang mempengaruhi pembiayaan yang disalurkan dimana terdapat rasiorasio keuangan yang dapat menilai kondisi internal perusahaan antara lain FDR atau kepanjangan dari Financing To Deposit Ratio merupakan faktor internal yang mewakili dari rasio likuiditas, serta yang mewakili dari rasio profitabilitas pada bank syariah maupun bank konvensional adalah ROA atau Return on Asset, dari kedua faktor tersebut terdapat faktor internal lain yang mempengaruhi pembiayaan yaitu DPK atau Dana Pihak Ketiga dan NPF atau Non Performing Financing terkait dengan pembiayaan bermasalah (Umiyati dan Leni, 2017).

Faktor kedua yaitu faktor ekternal yang dapat mempengaruhi pembiayaan pada bank syariah maupun lembaga keuangan lainnya adalah inflasi. Inflasi merupakan musuh terbesar bagi perekonomian, khususnya bagi bank syariah maupun bank konvensional. Pergerakan inflasi dari tahun ke tahun mengalami fluktuasi, hal ini dapat berpengaruh karena apabila inflasi tinggi akan berdampak pada nasabah yang ingin menabung karena nilai mata uang yang ditabung semakin rendah (Naufal dkk, 2017).

Faktor-faktor internal yang telah disebutkan diatas seperti Financing To Deposit Ratio (FDR), Dana Pihak Ketiga (DPK), dan Return On Asset (ROA). Ketiga faktor tersebut FDR, DPK, dan ROA berpengaruh positif terhadap pembiayan pada bank maupun lembaga keuangan, Financing to Deposit Ratio (FDR) dapat mempengaruhi pembiayaan bagi hasil seperti musyarakah jika Financing To Deposit Ratio tinggi menunjukkan bahwa semakin rendahnya kemampuan likuiditas bank yang bersangkutan atau semakin besar kredit maka pendapatan yang diperoleh naik, sehingga jika pendapatan naik laba juga akan mengalami kenaikan (Choirudin, 2017).

Dana Pihak Ketiga pada pembiayaan musyarakah jika semakin tinggi dana yang dihimpun dari masyarakat, bank mempunyai kesempatan lebih dalam menyalurkan dananya pada aset-aset produktif seperti pembiayaan (Setiawan dan Astiwi, 2016). Retrun On Asset dapat mempengaruhi pembiayaan apabila semakin tinggi ROA maka menunjukkan perusahaan yang semakin efisien dalam memperoleh laba sehingga nilai perusahaan meningkat (Ni'mah, 2015).

Berdasarkan latar belakang di atas peneliti memetahkan masalah penelitian apakah FDR berpengaruh terhadap produk pembiayaan musyarakah; apakah DPK berpengaruh terhadap produk pembiayaan musyarakah; apakah ROA berpengaruh terhadap produk pembiayaan musyarakah dan apakah FDR, DPK, ROA berpengaruh simultan atau bersama-sama terhadap pembiayaan musyarakah Bank Syariah Mandiri tahun 2010-2018.

\section{KAJIAN PUSTAKA}

Liliani dan Khairunnisa (2015). Pada penelitian ini yang berjudul Pengaruh Dana Pihak Ketiga (DPK), Non Performing Financing (NPF), Return On Asset (ROA) dan Capital Adequacy Ratio (CAR) Terhadap Pembiayaan Bagi Hasil Pada Bank Umum Syariah Di Indonesia Periode 2010-2013. Dimana pada penelitian ini dapat ditarik kesimpulan bahwa Berdasarkan hasil pengujian secara simultan dapat disimpulkan bahwa variabel Dana Pihak Ketiga (DPK), Non Performing Financing (NPF), Return On Asset (ROA) dan Capital Adequacy Ratio (CAR) berpengaruh secara simultan terhadap pembiayaan bagi hasil pada bank umum syariah di Indonesia periode 2010-2013. Hal ini dapat dilihat melalui nilai signifikansi pada ujiF yang menunjukkan nilai 0.000000 yang lebih kecil dibandingkan dengan tingkat signifikan 0.05 dan Dana Pihak Ketiga berpengaruh signifikan terhadap pembiayaan bagi hasil serta memiliki arah positif, semakin besar DPK yang dihimpun maka semakin besar pula tingkat pembiayaan bagi hasil kepada nasabah dengan nilai probabilitas $0,0104<0.05$. NPF tidak memiliki pengaruh signifikan secara parsial pada pembiayan bagi hasil dengan nilai probabilitas 0.9928 $>0.05$. ROA memiliki pengaruh yang signifikan secara parsial pada pembiayaan bagi hasil dengan nilai probabilitas $0.9928>0.05$, sedangkan CAR tidak memiliki pengaruh yang signifikan pada pembiayan bagi hasil dengan nilai probabilitas $0.0774>0.05$.

Gumilarty dan Indriani (2016). Penelitian dengan judul Analisis Pengaruh DPK, NPF, ROA, Penempatan Dana pada SBIS dan Tingkat Bagi Hasil Terhadap pembiayaan Bagi Hasil (Studi Pada Bank Umum Syariah di Indonesia Periode Tahun 20102014). Berdasarkan hasil uji hipotesis dapat dilihat 
bahwa variabel Dana Pihak Ketiga (DPK) berpengaruh positif signifikan terhadap pembiayaan bagi hasil dengan nilai signifikansi sebesar 0,000 . Variabel Non Performing Financing (NPF) berpengaruh positif signifikan terhadap pembiayaan bagi hasil dengan nilai signifikansi sebesar 0,007. Variabel Return On Asset (ROA) berpengaruh positif signifikan terhadap pembiayaan bagi hasil dengan nilai signifikansi sebesar 0,000 . Variabel Sertifikat Bank Indonesia Syariah (SBIS) berpengaruh positif tidak signifikan terhadap pembiayaan bagi hasil dengan nilai signifikansi sebesar 0,069. Variabel tingkat bagi hasil (TBHt-1) berpengaruh negatif tidak signifikan terhadap pembiayaan bagi hasil dengan nilai signifikansi sebesar 0,312 .

Murniati dan Firsta (2018). Penelitian yang berjudul Pengaruh DPK, NPF, CAR dan ROA Terhadap Pembiayaan Mudharabah dan Musyarakah Pada Bank Syariah Mandiri Periode 2011-2016 berdasarkan uji hipotesis dapat dilihat bahwa variabel DPK mempunyai tidak pengaruh baik terhadap mudharabah maupun musyarakah. Hal ini dapat dilihat dari nilai signifikansi mudharabah $(0.138>$ $0.05)$ dan nilai signifikansi musyarakah (0.234 > 0.05). Maka dapat dikatakan Ho diterima dan menolak Ha. Berdasarkan uji hipotesis dapat dilihat bahwa variabel NPF mempunyai pengaruh terhadap mudharabah.

\section{Pembiayaan}

Pembiayaan adalah suatu aktivitas pada bank syariah yaitu menyalurkan dana kepada pihak lain berdasarkan prinsip syariah. penyaluran dana didasarkan pada prinsip kepercayaan yang diberikan oleh pemilik dana kepada pengguna dana. Pihak pemilik dana percaya bahwa dana dalam bentuk pembiayaan yang diberikan pasti akan terbayar, begitu juga dengan pihak pengguna dana juga akan mendapatkan kepercayaan dari pemberi pembiayaan sehingga penerima pembiaayaan berkewajiban mengembalikan pembiayaan yang telah diterimanya (Ismail, 2011).

Pembiayaan pada prinsip syariah adalah pembiayaan yang menyediakan uang maupun tagihan berdasarkan atas persetujuan ataupun kesepakatan antara pihak perbankan dengan pihak lain yang mempunyai kewajiban pihak yang dibiayai untuk mengembalikan uang maupun tagihan tersebut setelah jangka waktu tertentu dengan imbalan maupun bagi hasil (Asri dan Syaicu, 2016).
Pembiayaan adalah suatu aktivitas maupun kegiatan dimana kegiatannya berupa penyaluran dana untuk disalurkan kepada pihak lain selain lembaga keuangan ataupun bank yang berdasarkan dengan prinsip-prinsip syariah. Pembiayaan artinya kepercayaan atau trust dalam artian lembaga pembiayaan selaku shahibul maal memberikan kepercayaan kepada nasabah untuk melaksanakan amanah yang diberikan dan dana tersebut digunakan dengan benar, adil dan disertai dengan ikatan dan syarat jelas serta saling menguntungkan bagi kedua belah pihak (Rivai dan Veithzal, 2008). Pembiayaan adalah pendanaan yang diberikan oleh satu pihak kepada pihak lain untuk mendukung investasi yang telah direncanakan baik dalam perencanaannya dilakukan sendiri maupun dilakukan oleh lembaga (Al-Arief, 2010).

Menurut Undang-Undang No 10 tahun 1998 tentang Perbankan, pembiayaan adalah penyediaan uang atau tagihan yang dapat di persamakan dengan itu, berdasarkan persetujuan atau kesepakatan antara bank dengan pihak lain yang mewajibkan pihak yang dibayarkan untuk mengembalikan uang atau tagihan tersebut setelah waktu tertentu dengan imbalan atau bagi hasil.

\section{Lembaga keuangan}

Lembaga keuangan merupakan kata yang berasal dari bahasa inggris yaitu Financial Institution, dimana lembaga keuangan mempunyai arti yaitu suatu badan usaha yang kegiatannya yang bergerak dalam bidang jasa dalam menjalankan usahanya seperti melakukan funding maupun financing dengan tujuan untuk memenuhi kebutuhan masyarakat. Pengertian lain dari lembaga keuangan adalah suatu badan yang kegiatannya dalam bidang keuangan dengan melakukan penghimpunan maupun penyaluran dana kepada masyarakat (Mahbub, 2016). Secara umum lembaga keuangan berperan sebagai lembaga intermediasi.

Lembaga keuangan syariah adalah suatu lembaga yang kegiatannya berkaitan dengan keuangan baik berupa kegiatan penghimpun dana maupun kegiatan penyaluran dana (Soemitra, 2010). Menurut Sri Susilo, dkk. (2000) lembaga keuangan adalah suatu lembaga atau badan yang bergerak dalam bidang keuangan yang mencakup penghimpunan dan penyaluran dana atau dari nasabah untuk nasabah, serta berguna dalam membiayai investasi perusahaan.

Berdasarkan pengertian-pengertian diatas penulis dapat menyimpulkan bahwa lembaga keuangan sangat 
membantu dalam menyediakan dana kepada masyarakat untuk melakukan usaha atau membuka usaha. Tidak hanya membantu saja namun juga dapat mensejahterahkan masyarakat serta meningkatkan pendapatan masyarakat, dan meningkatkan ekonomi masyarakat.

\section{Bank Syariah}

Perbankan diatur dalam Undang-Undang No. 21 Tahun 2008 yang berbunyi bahwa perbankan syariah adalah segala sesuatu yang menyangkut tentang bank syariah dan Unit Usaha Syariah, mencakup kelembagaan, kegiatan usaha, serta tatacara dan proses dalam melaksanakan kegiatan usahanya. Bank dibagi menjadi dua yaitu bank syariah dan bank konvensional, bank syariah merupakan bank yang kegiatan usahanya sesuai dengan prinsip-prinsip syariah dan sistem keuntungannya dengan metode bagi hasil, margin maupun fee.

Bank syariah adalah bank bank yang yang beroperasi dengan tidak mengandalkan pada bunga, lembaga keuangan syariah atau bank syariah adalah suatu lembaga yang yang beroperasional serta produknya yang dikembangkan berlandaskan pada $\mathrm{Al}$ Qur'an dan Hadist Nabi SAW (Muhammad, 2011).

Bank syariah adalah bank dimana yang berasaskan pada kemitraan, keadilan, transparasi dan universal serta melakukan kegiatan usaha perbankan berdasakan prinsip syariah. kegiatan bank syariah melakukan implementasi dari prinsip ekonomi Islam dengan karakteristik seperti pelarangan riba, tidak mengenal konsep uang sebagai nilai waktu dari uang, konsep uang sebagai alat tukar bukan sebagai komoditas (Susyanti, 2016).

\section{Musyarakah}

Secara bahasa musyarakah berasal dari kata syirkah yang berarti adalah al-ikhtilath atau yang biasa dikenal dengan percampuran tidak hanya percampuran saja namun juga berkaitan dengan persekutuan, percampuran yang dimaksud adalah bercampurnya salah satu dari dua harta dengan harta lainnya tanpa adanya perbedaaan antara keduanya. Para fiqih mengartikan sebagi akad antara dua sekutu yang berkaitan dengan modal beserta keuntungannya (Waluyo, 2014).

Musyarakah adalah suatu akad yang berlandaskan kerjasama antara dua pihak ataupun lebih dimana keduanya melakukan suatu usaha tertentu dengan sejumlah modal yang telah ditetapkan berdasarkan perjanjian dengan tujuan untuk bersamasama menjalankan suatu usaha yang dilakukan bersama dan pembagian keuntungan ataupun kerugian dalam bagian yang ditentukan (Nawawi, 2012), sedangkan menurut istilah fiqih, syirkah merupakan akad kerjasama antara dua orang atau lebih untuk melakukan perkongsian modal, tidak hanya itu saja namun bersekutu dalam keuntungan (IBI, 2003).

\section{Financing To Deposit Ratio (FDR)}

Financing To Deposit Ratio (FDR) adalah rasio yang menggambarkan tingkat kemampuan bank syariah atau dalam pengertian lain adalah rasio dari jumlah kredit yang diberikan bank kepada nasabah dengan dana yang diterima bank dari nasabah dengan kata lain menyediakan dana dari kepada debitur dengan dana yang dikumpulkan oleh masyarakat (Dendawijaya, 2005).

FDR atau Financing To Deposit Ratio merupakan rasio yang digunakan untuk mengukur suatu jumlah pembiayaan yang diberikan dengan jumlah dana masyarakat dan modal sendiri yang digunakan (Kasmir, 2012). FDR adalah kemampuan bank khususnya bank syariah dalam mengembalikan dana kepada pihak ketiga melalui keuntungan yang didapat dari pembiayaan musyarakah (Ranchman, 2015). FDR adalah perbandingan antara pembiayaan yang diberikan oleh bank dengan dana pihak ketiga yang berhasil dikerahkan oleh bank (Muhammad, 2005).

\section{Pengertian Dana Pihak Ketiga (DPK)}

DPK atau yang biasa disebut dengan Dana Pihak Ketiga merupakan dana yang berasal dari masyarakat yang melakukan pembiayaan, maupun menabung, dengan berbagai produk simpanan yang dimiliki oleh bank. Pada DPK ini terdapat 2 metode yang diterapkan diperbankan syariah yaitu wa'diah (berupa simpanan) dan mudharabah (Kuncoro, 2002). DPK merupakan hal yang penting bagi bank karena DPK dapat meningkatkan kualitas bank, jika tidak ada DPK bank juga tidak akan bisa melakukan penyaluran maupun penyimpanan dana.

DPK merupakan aset paling besar dan yang paling diandalkan oleh bank bisa mencapai $80 \%$ sampai 90\%, DPK merupakan salah satu sumber yang dapat digunakan untuk pembiayaan. Semakin besar bank berhasil menghimpuna dana dari pihak DPK maka semakin besar pula pembiayaan yang disalurkan oleh bank (Destiana, 2016).

DPK adalah sejumlah uang yang dimiliki bank dimana uang tersebut berasal dari pihak luar yang menyimpan uangnya atau uang yang dimiliki bukan milik bank sendiri melainkan titipan dari pihak luar, 
dan bank disini hanya sebagai lembaga yang bertugas menghimpun serta disalurkan kembali kepada masyarakat (Saputra, 2014).

\section{Pengertian Return On Asset (ROA)}

Return On Asset adalah suatu rasio yang digunakan untuk mengukur kemampuan manajemen dalam menghasilkan atau memperoleh keuntungan bagi perusahaan keuntungan disini yang dimaksud adalah keuntungan setelah pajak yang dihasilkan dari rata-rata total aset bank yang bersangkutan (Subramayam dkk, 2013).

ROA adalah hasil return yang didasarkan pada jumlah aktiva yang digunakan di dalam perusahaan maupun pada lembaga keuangan. ROA merupakan ukuran efektivitas manajemen dalam mengelola asetnya (Kasmir, 2010). Menurut Sutrisno (2009), ROA merupakan bagian dari rentabilitas yang merupakan kemampuan perusahaan dalam menghasilkan laba dengan semua aktiva yang dimiliki perusahaan.

ROA merupakan rasio dari profitabilitas yang digunakan untuk mengukut kemampuan bank dalam mencapai keuntungan secara menyeluruh serta dalam meningkatkan pada tingkat pendapatan, aset, modal saham dan menilai kemampuan manajemen dalam mengendalikan biaya-biaya agar dapat menggambarkan produktivitas bank tersebut (Meydianawati, 2007).

\section{METODE PENELITIAN}

Jenis dari penelitian ini adalah berbentuk kuantitatif. Pada penelitian ini populasi yang diambil pada perbankan syariah yaitu pada Bank Syariah Mandiri, pada Bank Syariah Mandiri ini terdapat pembiayaan musyarakah, tidak hanya musyarakah saja namun pada perbankan tersebut terdapat pembiayaan yang lainnya seperti mudharabah, murabahah, qard, ijarah, wadiah dll, sehingga populasi pada penelitian ini menggunakan populasi bank yang berbasis syariah yaitu Bank Syariah Mandiri dimana peneliti melakukan penelitian dari tahun 2010-2018. Sedangkan ddata untuk penelitian tersedia antara tahun 2010-2018 dalam bentuk laporan keuangan triwulan yaitu 32 sampel. sampel pada penelitian maximal 30 sampel namun pada penelitian ini dikarenakan pada laporan keuangan triwulan setiap per tahun terdapat 4 laporan keuangan jadi 8 tahun $\mathrm{x} 4$ $=32$ sampel. Sedangkan metode analisis menggunakan Uji Statistik dan Uji Asumsi Klasik.

\section{Pembahasan}

\section{a. Uji asumsi klasik}

Sebelum melakukan pengujian hipotesis, terlebih dahulu dilakukan pengujian terhadap gejala penyimpangan klasik. Adapun uji asumsi klasik terdapat empat uji diantaranya adalah uji normalitas, uji multikolonieritas, uji heteroskedastisitas, dan uji autokorelasi (Ghozali, 2011). Berikut adalah hasil uji asumsi klasik yang terdiri dari uji normalitas, uji multikolonieritas, uji heteroskedastisitas, dan uji autokorelasi.

1) Uji Normalitas

Pada uji normalitas ini menggunakan uji Kolmogorov-Smirnov. Uji ini dilakukan untuk membandingkan probabilitas yang diperoleh dari hasil signifikan 0.05 , dengan ketentuan jika nilai sign hitung > 0,05 maka data yang diolah normal. Berikut hasil uji normalitas adalah sebagai berikut:

Tabel Uji Normalitas

\begin{tabular}{|c|c|c|}
\hline $\begin{array}{c}\text { Sign } \\
\text { Hitung }\end{array}$ & Signifikansi & Keterangan \\
\hline 0,2 & 0,05 & $\begin{array}{c}\text { Data berdistribusi } \\
\text { normal }\end{array}$ \\
\hline
\end{tabular}

Sumber: Data Sekunder yang diolah melalui SPSS 23, 2016

Berdasarkan tabel diatas nilai menunjukkan hasil normalitas pada nilai sign sebesar 0,2 sedangkan nilai ( $\alpha$ ) 0,05 . Hal ini uji normalitas berdistribusi normal karena nilai sign lebih besar dari nilai $(\alpha)$ atau $0,2>$ 0,05 . Jadi secara keseluruhan dapat disimpulkan bahwa model regresi telah lolos uji normalitas.

2) Uji Multikolinieritas

Jika nilai tolerance rendah maka nilai VIF tinggi karena $\mathrm{VIF}=1 /$ Tolerance, menunjukkan adanya multikolinieritas karena nilai tolerance $>0,10$ atau sama dengan nilai VIF $<10.00$. Jika nilai tolerance $<$ 0,10 atau sama dengan VIF $>10$ maka terjadi gangguan pada penelitian namun jika multikolinieritas yang dilihat dari nilai VIF dan tolerance value apabila terdapat kriteria nilai tolerance $>0,10$ dan VIF $<10.00$ dapat diartikan tidak terdapat multikolinieritas pada penelitiain tersebut (Ghozali, 2013). Berikut hasil dari uji multikolonieritas.

Tabel Uji Multikolinieritas

\begin{tabular}{|l|c|c|l||}
\hline \multicolumn{1}{|c|}{ Variabel } & Tolerance & VIF & \multicolumn{1}{|c|}{ Keterangan } \\
\hline Financing & 0,754 & 1,327 & $\begin{array}{l}\text { Tidak terjadi } \\
\text { To Deposit }\end{array}$ \\
Ratio (FDR) & & & Multikolinieritas \\
\hline
\end{tabular}


Jurnal Ilmiah Ekonomi Islam, 6(03), 2020, 604

\begin{tabular}{||l|c|c|l|}
\hline Variabel & Tolerance & VIF & Keterangan \\
\hline $\begin{array}{l}\text { Dana Pihak } \\
\text { Ketiga (DPK) }\end{array}$ & 0,836 & 1,197 & $\begin{array}{l}\text { Tidak terjadi } \\
\text { Multikolinieritas }\end{array}$ \\
\hline $\begin{array}{l}\text { Return On } \\
\text { Asset } \text { (ROA) }\end{array}$ & 0,872 & 1,147 & $\begin{array}{l}\text { Tidak terjadi } \\
\text { Mulitikolinieritas }\end{array}$ \\
\hline
\end{tabular}

Sumber: Data Sekunder yang diolah melalui SPSS 23, 2016

Dari hasil pengujian Multikolinieritas diatas menunjukkan bahwa semua model regresi mempunyai nilai tolerance pada variabel Financing To Deposit Ratio (FDR) mempunyai nilai tolerance 0,754, Dana Pihak Ketiga (DPK) mempunyai nilai tolerance 0,836 sedangkan Return On Asset (ROA) mempunyai nilai tolerance sebesar 0,872 , sehingga dari hasil nilai tolerance FDR, DPK dan ROA > 0,10, sedangkan pada nilai VIF dari variabel Financing To Deposit Ratio (FDR) mempunyai nilai VIF sebesar 1,327, Dana Pihak Ketiga (DPK) mempunyai nilai VIF sebesar 1,197 dan Return On Asset mempunyai nilai VIF sebesar 1,147 sehingga dari hasil VIF tersebut variabel FDR, DPK dan ROA < 10.00. hal ini dapat disimpulkan bahwa tidak ada gejala multikolinieritas dalam model regresi yang digunakan.

3) Heterokedastisitas

Uji Heterokedastisitas sebuah pengujian digunakan untuk mengetahui apakah dalam model regresi terjadi ketidaksamaan variance dari residual pengamatan ke pengamatan yang lain. Model regresi ini yang baik adalah tidak terjadi Heterokedastisitas. Pada uji ini apabila nilai sign pada tabel coefisient jika sign $<0,05$ maka terjadi heterokedastisitas namun jika sig $>0,05$ tidak terjadi heteroskedastisitas. Berikut hasil dari heteroskedastisitas.

Tabel Uji Heterokedastisitas

\begin{tabular}{|l|c|c|}
\hline \multicolumn{1}{|c|}{ Variabel } & Sig & Keterangan \\
\hline $\begin{array}{l}\text { Financing To } \\
\text { Deposit Ratio } \\
\text { (FDR) }\end{array}$ & 0,949 & $\begin{array}{c}\text { Tidak terjadi } \\
\text { Heterokedastisitas }\end{array}$ \\
\hline $\begin{array}{l}\text { Dana Pihak } \\
\text { Ketiga (DPK) }\end{array}$ & 0,383 & $\begin{array}{c}\text { Tidak terjadi } \\
\text { Heterokedastisitas }\end{array}$ \\
\hline $\begin{array}{l}\text { Return On } \\
\text { Asset } \text { (ROA) }\end{array}$ & 0,077 & $\begin{array}{c}\text { Tidak terjadi } \\
\text { Heterokedastisitas }\end{array}$ \\
\hline
\end{tabular}

Sumber: Data Sekunder yang diolah melalui SPSS 23, 2016

Berdasarkan tabel diatas merupakan hasil dari uji heterokedastisitas dan pada tabel diatas dilihat dari nilai sig menunjukkan bahwa variabel pada Financing To Deposit Ratio (FDR) mempunyai nilai sig sebesar

0,949, Dana Pihak Ketiga (DPK) mempunyai nilai sig sebesar 0,383 dan Return On Asset mempunyai nilai sig sebesar 0,077 dari nilai sig setiap variabel menunjukkan bahwa lebih besar dari 0,05. Jadi hasil diatas dapat disimpulkan bahwa tidak terjadi heterokedastisitas pada model regresi yang digunakan. 4) Autokorelasi

Deteksi adanya suatu autokorelasi dengan menggunakan uji Durbin-Watson, dimana jika DW diantara -2 sampai +2 berarti tidak ada autokorelasi, jika angka D-W dibawah -2 maka terjadi autokorelasi positif, dan jika angka D-W diatas +2 maka terjadi autokorelasi namun negatif (Santoso, 2001:219). Hasil ini dapat dilihat sebagai berikut:

Tabel Uji Autokorelasi Model Summary ${ }^{\mathrm{a}, \mathrm{b}}$

\begin{tabular}{|l|c|r|r|r|r|}
\hline Model & $\mathrm{R}$ & $\begin{array}{c}\mathrm{R} \\
\text { Square }^{\mathrm{b}}\end{array}$ & $\begin{array}{c}\text { Adjusted } \\
\text { R Square }\end{array}$ & $\begin{array}{c}\text { Std. Error } \\
\text { of the } \\
\text { Estimate }\end{array}$ & $\begin{array}{l}\text { Durbin- } \\
\text { Watson }\end{array}$ \\
\hline 1 & $.940^{0}$ & .884 & .872 & $\begin{array}{r}1110143.0 \\
2693\end{array}$ & 2.115 \\
\hline
\end{tabular}

Sumber: Data sekunder yang diolah melalui SPSS, 2016

Pada tabel diatas bahwa autokorelasi dapat dilihat dari angka statistik durbin-watson yang nilainya sebesar 2,115, $\mathrm{N}=32$ dan $\mathrm{k}=3$, taraf signifikansi yang digunakan $(\alpha)$ adalah 5\% diperoleh $\mathrm{d}_{\mathrm{L}}$ sebesar 1.2437 dan nilai $d_{U}$ sebesar 1.6505 serta $4-d_{U}$ sebesar 2,3493 dan 4- $d_{L}$ sebesar 2.7563 dapat dilihat pada table di bawah.

Tabel Batas-batas Daerah Test Durbin-Watson

\begin{tabular}{|c|c|}
\hline Distribusi & Interpretasi \\
\hline $\mathrm{DW}<2,115$ & Autokorelasi positif \\
$1,2437 \leq \mathrm{DW}<1,6505$ & Daerah keragu-raguan/ \\
& Incilclusif \\
$1,6505 \leq \mathrm{DW}<2,3495$ & Tidak ada autokorelasi \\
$2,3495 \leq \mathrm{DW}<2,7563$ & Daerah keragu-raguan/ \\
& Incilclusif \\
$\mathrm{DW} \geq 2,7563$ & Autokorelasi negative \\
\hline
\end{tabular}

\section{b. Uji Regresi Linier Berganda}

Model regresi berganda adalah teknik analisis regresi yang menjelaskan suatu hubungan antara variabel dependen dengan variabel indenpenden. Hal ini bertujuan agar dapat diketahui nilai duga rata-rata variabel dependen atas pengaruh variabel independen tersebut. Berikut Persamaan dari model regresi linier berganda: 
$\mathrm{Y}=\mathrm{a} 0+\beta 1 \mathrm{X} 1+\beta 2 \mathrm{X} 2+\beta 3 \mathrm{X} 3+e$

Keterangan:

$\mathrm{Y}=$ pembiayaan musyarakah

$\mathrm{a}=$ konstanta

$\mathrm{X} 1=$ Financing To Deposit Ratio (FDR)

$\mathrm{X} 2=$ Dana Pihak Ketiga $(\mathrm{DPK})$

$\mathrm{X} 3=$ Return On Asset (ROA)

$\mathrm{E}=$ Random Error atau Variabel ganggungan

$\beta 1, \beta 2, \beta 3=$ Koefisien regresi Linear masing-masing variabel independen.

Pada regresi linier berganda ini dalam mengolahnya menggunakan aplikasi SPSS versi 23 . Berikut adalah hasil dari Regresi linier berganda

Tabel Uji Regresi Linier Berganda

Coefficients $^{\mathrm{a}}$

\begin{tabular}{|ll|r|r|}
\hline \multirow{2}{*}{ Model } & \multicolumn{2}{|c|}{ Unstandardized Coefficients } \\
\cline { 2 - 3 } \multicolumn{2}{|l|}{ (Constant) } & \multicolumn{1}{|c|}{ B } & \multicolumn{1}{c|}{ Std. Error } \\
\hline & FDR & -6282165.434 & 11917976.878 \\
& DPK & 1.348 & 129193.087 \\
ROA & 451703.980 & .296 \\
&
\end{tabular}

Sumber: Data sekunder yang diolah melalui SPSS 23, 2016

Dari hasil output regresion dengan menggunakan alat bantu SPSS 23 sehingga dapat diperoleh persamaan regresi diatas adalah sebagai berikut:

$\mathrm{Y}=\mathrm{a}+\mathrm{b} 1 \mathrm{X} 1+\mathrm{b} 2 \mathrm{X} 2+\mathrm{b} 3 \mathrm{X} 3+\mathrm{e}$

Pembiayaan musyarakah $=48282165.434$

635141.239 FDR + 1.348 DPK + 451703.980 ROA + e

\section{c. Uji Statistik}

Tabel Uji t

\begin{tabular}{||l|l|l|l|l|l|}
\hline \multicolumn{1}{|c|}{ Keterangan } & \multicolumn{1}{c|}{$\mathbf{t}_{\text {hitung }}$} & $\mathbf{t}_{\text {tabel }}$ & \multicolumn{1}{c|}{ Sig } & \multicolumn{1}{c|}{ Hipotesis } & \multicolumn{1}{c|}{ Keterangan } \\
\hline Financing To Deposit Ratio (FDR) & $-4,916$ & 2,0484 & 0,000 & Terima H1 & Berpengaruh \\
\hline Dana Pihak Ketiga (DPK) & 4,559 & 2,0484 & 0,000 & Terima H2 & Berpengaruh \\
\hline Return On Asset (ROA) & 0,805 & 2,0484 & 0,428 & Tolak H3 & Tidak berpengaruh \\
\hline
\end{tabular}

Sumber: Data sekunder yang diolah melalui SPSS 23, 2016

a. Hasil uji t dengan cara membandingkan antara $t_{\text {hitung }}$ dengan $t_{\text {tabel }}$. Apabila $t_{\text {hitung }}$ lebih besar dari $t_{\text {tabel }}$ maka variabel indenpenden berpengaruh terhadap variabel dependen namun apabila $t_{\text {hitung }}$ lebih kecil dari tabel maka variabel independen tidak berpengaruh terhadap variabel dependen sehingga pada penelitian ini nilai yang dihasilkan dari $t_{\text {tabel }}$ adalah sebesar 2,0484 sedangkan variabel Financing To Deposit Ratio (FDR) nilai $\mathrm{t}_{\text {hitung }}$ sebesar $-4,916$, dari hasil $\mathrm{t}_{\text {hitung }}$ dengan $\mathrm{t}_{\text {tabel }}$ bahwa $t_{\text {hitung }}$ lebih besar dari pada $t_{\text {tabel }}$ atau $-4,916$ > 2,0484 sehingga dapat diartikan bahwa variabel Financing To Deposit Ratio (FDR) secara statistik berpengaruh negatif terhadap pembiayaan musyarakah Bank Syariah Mandiri periode 20102017.

Dari hasil uji t pada variabel Financing To Deposit Ratio (FDR) berpengaruh namun negatif. berpengaruh FDR terhadap pembiayaan musyarakah karena menyediakan dana bagi nasabah yang bersangkutan melakukan pembiayaan sedangkan negatifnya apabila FDR tinggi maka semakin rendah kemampuan likuiditas bank yang bersangkutan sehingga menyebabkan bank akan mengalami kerugian apabila tidak mampu membayar suatu kewajiban atau terjadi suatu resiko karena pembiyaan musyarakah merupakan pembiayaan yang berisiko.

Pada penelitian ini nilai yang dihasilkan dari $t_{\text {tabel }}$ adalah sebesar 2,0484 sedangkan variabel Dana Pihak Ketiga (DPK) nilai thitung sebesar 4,559, dari hasil nilai $t_{\text {hitung }}$ dengan $t_{\text {tabel }}$ bahwa $t_{\text {hitung }}$ lebih besar dari pada $t_{\text {tabel }}$ atau 4,559>2,0484 sehingga dapat diartikan bahwa variabel Dana Pihak Ketiga (DPK) secara statistik berpengaruh terhadap pembiayaan musyarakah Bank Syariah Mandiri periode 2010-2017.

Dari hasil uji t diatas terkait dengan variabel Dana Pihak Ketiga berpengaruh positif terhadap pembiayaan musyarakah hal ini disebabkan karena Dana Pihak Ketiga merupakan sumber atau aliran dana utama bank yang berasal dari nasabah yang melakukan simpanan seperti giro, tabungan dan deposito. Hal ini sangat berpengaruh sekali apabila Dana Pihak Ketiga meningkat, maka transaksi pembiayaan musyarakah juga akan meningkat. DPK ini sangat penting sekali bagi bank jika tidak ada DPK maka bank juga tidak akan bisa melakukan transaksi dan bank bisa dikatakan tidak baik jika tidak ada DPK yang melakukan transaksi.

Hasil uji t terhadap variabel rasio Return On Asset (ROA) memperoleh nilai signifikansi $=0,428>$ 
0,05 atau $P$-value $>\alpha$ yaitu $0,428>0,05$ maka $\mathrm{H} 0$ diterima dan $\mathrm{H} 3$ ditolak, artinya variabel rasio Return On Asset (ROA) tidak berpengaruh terhadap pembiayaan musyarakah laporan triwulan Bank Syariah Mandiri tahun 2010-2017. Pada penelitian ini nilai yang dihasilkan dari $t_{\text {tabel }}$ adalah sebesar 2,0484 sedangkan variabel rasio Return On Asset (ROA) nilai thitung sebesar 0,805, dari hasil nilai $t_{\text {hitung }}$ dengan $t_{\text {tabel }}$ bahwa $t_{\text {hitung }}$ lebih kecil dari pada $t_{\text {tabel }}$ atau 0,805>2,0484 sehingga dapat diartikan bahwa variabel Return On Asset (ROA) secara statistik tidak berpengaruh terhadap

Tabel Uji F

\begin{tabular}{|c|c|c|c|c|c||}
\hline Keterangan & $\mathbf{F}_{\text {hitung }}$ & $\mathbf{F}_{\text {tabel }}$ & signifikansi & Hipotesis & Hasil \\
\hline Variabel secara simultan & 25,160 & 2.95 & 0,000 & Terima H4 & Berpengaruh \\
\hline
\end{tabular}

Sumber: Data sekunder yang diolah melalui SPSS 23, 2016

b. Dari uji $F$ pada tabel diatas didapat $F_{\text {hitung }}$ sebesar 25,160 dengan probabilitas $0,000<0,05$. Jika membandingkan antara $F_{\text {hitung }}$ dengan $F_{\text {tabel }}$, bahwa nilai dari $F_{\text {hitung }}$ sebesar 25,160 dan $F_{\text {tabel }}$ sebesar 2.95 maka 25,160 > 2,95 dari hasil tersebut dapat disimpulkan bahwa variabel Financing To Deposit Ratio (FDR), Dana Pihak Ketiga (DPK) dan Return On Asset (ROA) bersama-sama berpengaruh terhadap pembiayaan musyarakah, sehingga pemilihan variabel Financing To Deposit Ratio (FDR), Dana Pihak Ketiga (DPK) dan Return On Asset (ROA) sebagai predictor pembiayaan musyarakah pada Bank Syariah Mandiri periode 2010-2018 sudah tepat.

\section{KESIMPULAN}

Berdasarkan hasil analisis yang telah dilakukan maka dapat diambil kesimpulan sebagai berikut:

a. Hasil pengujian hipotesis pertama yang dilakukan dengan menggunakan uji t diperoleh nilai variabel Financing To Deposit Ratio (FDR) dilihat dari nilai $t_{\text {hitung }}$ sebesar $-4,916$ dan nilai $t_{\text {tabel }}$ sebesar 2,0484 bahwa dari nilai tersebut $t_{\text {hitung }}>t_{\text {tabel }}$ sedangkan pada nilai $P$-value (sig) didapatkan sebesar $0,000<0,05$. Oleh karena itu, hipotesis kesatu dapat diterima sehingga variabel Financing To Deposit Ratio (FDR) berpengaruh negatif terhadap pembiayaan musyarakah pada Bank Syariah Mandiri (BSM) dari tahun 2010-2018.

b. Hasil pengujian hipotesis kedua yang dilakukan dengan menggunakan uji t diperoleh nilai variabel Dana Pihak Ketiga (DPK) dilihat dari nilai thitung untuk variabel DPK adalah 4,559 dan nilai $t_{\text {tabel }}$ pembiayaan musyarakah Bank Syariah Mandiri periode 2010-2018.

Dari hasil uji t pada variabel Return On Asset tidak berpengaruh terhadap musyarakah. Hal ini disebabkan karena musyarakah merupakan pembiayaan yang berisiko, resiko dari pembiayaan ini seperti resiko kerugian, gagal bayar sehingga mempengaruhi Retrun On Asset atau dalam hal mengelola assetnya dan dana pembiayaan yang keluar tidak terlalu banyak dipengaruhi oleh besar kecilnya ROA. 
Surakarta dan khususnya kepada Kemendikbud yang telah memsupport atas terlaksananya penelitian ini.l

\section{DAFTAR PUSTAKA}

Al Arief, Nur Rianto (2012). Lembaga Keuangan Syariah. Bandung:Pustaka Setia

Annisa,Suci \& Dedi Fernanda.(2017). Pengaruh DPK.CAR, NPF, dan ROA terhadap pembiayaan Mudharabah dan Musyarakah pada Bank Syariah Mandiri periode 2011-2015. Jurnal Ekonomi dan Bisnis Dharma Andalas. Vol 19 No 2

Asri, Aida Sania dan Syaicu. (2016) Analisis Factor Yang Mempengaruhi Pembiayaan Berbasis Bagi Hasil Pada Perbankan Di Indonesia Periode 2010-2014. Diponegoro Journal Of Management. Vol 5 no 3

Choiruddin, Ahmad.(2017) Analisis Faktor Yang Mempengaruhi Pembiayaan Bagi Hasil Mudharabah Pada Bank Umum Syariah. Jurnal Ilmu dan Riset Akuntansi. Vol 6 no 9

Dendawijaya, Lukman. (2005) Manajemen Perbankan edisi 2. Bogor:Ghalia Indonesia

Destiana,Rina.(2016).Analisis DPK dan risiko terhadap pembiayaan Mudharabah dan Musyarakah pada Bank Syariah Indonesia. Jurnal Logika. Vol XVII No 2

Ghozali, Imam (2011) Aplikasi Analisis Multivariate dengan Program IBM SPSS 19. Semarang: Badan Penerbit Universitas Diponegoro

Gumilarty, Gittrys Ratu Mashita dan Astiwi Indriani. 2016.Analisis Pengaruh DPK, NPF, ROA, Penempatan Dana Pada SBIS dan tingkat Bagi Hasil Terhadap Pembiayaan Bagi Hasil (Studi Pada Bank Umum Syariah di Indonesia Periode tahun 2010-2014). Diponegoro Journal of Management. Vol 5 No 4

Institut Bankir Indonesia (2003) Bank Syariah: Konsep, Produk Dan Implementasi Operasional. Jakarta:Djambatan

Ismail (2011) Perbankan Syariah. Jakarta:Kencana Prenada Media Group

Kasmir (2010) Analisis Laporan Keuangan. Jakarta:Raja Grafindo Persada

Kuncoro (2002) Manajemen Perbankan, Teori dan Aplikasi. Jakarta:PT Indeks Kelompok Gramedia Liliani dan Khairunnisa (2015) Pengaruh DPK, NPF, ROA, CAR terhadap pembiayaan bagi hasil pada Bank Umum Syariah di Indonesia Periode 20102013. E-procceding of Management, Vol 2 No 3
Mahbub, M. (2016) Pengaruh Pembiayaan Mudharabah Terhadap Pendapatan BMT UGT Sidogiri Capem Songgon Kabupaten Banyuwangi. Jurnal Hukum Islam. Vol 2 No 2

Meydianawati, L.G.(2007) Analisis Perilaku Penawaran Kredit Perbankan Kepada Sektor UMKM di Indonesia (2002-2006). Buletin Studi Ekonomi 12(2)

Mudrajat,Kuncoro \& suhardjono. (2002) Manajemen Perbankan: Teori \& Aplikasi. Yogyakarta:BPFE

Muhammad (2005) Manajeman Bank Syariah. Yogyakarta: UPP AMP YKPN

Muhammad (2011) Manajemen Bank Syariah. Yogyakarta:YKPN

Muniarti dan Firsta. (2018) Pengaruh DPK, NPF, CAR, ROA Terhadap Pembiayaan Mudharabahdan Musyarakah pada Bank Syariah Mandiri Periode 2011-2016. Jurnal Ekonomi dan Bisnis. Vol 20 No 1

Naufal, Tanesia, Sri Fadillah dan Helliana (2017) Pengaruh Dana Pihak Ketiga, Rasio Keuangan Bank, Inflasi dan Bi Rate Terhadap Volume Pembiayaan (Studi pada Bank Umum Syariah yang terdaftar di Bank Indonesia Periode 20122016. Prosiding Akuntansi, Vol 3 No 2

Nawawi, Ismail. (2012) Fikih Muamalah Klasik dan Kotemporer. Bogor: Ghadia Indonesia

Ni'mah, Kholisatun (2015) Analisis Pengaruh Dana Pihak Ketiga (DPK), Modal Sendiri, Return On Asset (Roa) Dan Financing To Deposit Ratio (Fdr) Terhadap Pembiayaan Yang Disalurkan Pada Bank Bri Syariah Pada Tahun 2010-2014. Skripsi. Fakultas Ekonomi Dan Bisnis Islam Universitas Islam Negeri Walisongo Semarang.

Ranchman, Yoga Tantular(2015), Pengaruh Financing To Deposit Ratio (FDR), Non Performing Financing (NPF), Return On Asset (ROA), Capital Adequacy Ratio (CAR) terhadap pembiayaan mudharabah (survey pada Bank Syariah yang Listing di Bursa Efek Indonesia Tahun 2009-2013. Proceeding Icief 15, Mataram 25-27 Agustus 2015

Rivai dan Veithzal.(2008), Islamic Financial Managemen. Jakarta: Raja Grafindo Persada

Saputra, Imam Rifky. (2014), Pengaruh DPK dan NPF Terhadap Pembiayaan Yang Disalurkan (PYD) Serta Implikasinya Pada Roa (Studi Pada 3 Bank Umum Syariah Di Indonesia periode 2010-2013). Skripsi. Fakultas Syariah dan Hukum UIN Syarif Hidayahtullah: Jakarta 
Jurnal Ilmiah Ekonomi Islam, 6(03), 2020, 608

Setiawan, Ulin dan Astiwi.(2016), Pengaruh Dana Pihak Ketiga (DPK), Capital Adequecy Ratio (CAR), Non Performing Financing (NPF) terhadap profitabilitas Bank Syariah dengan Pembiayaan Sebagai Variabel Intervering. Diponegoro Journal Of Management. Vol 5 no 4 Soemitra, Andri. (2009), Bank dan Lembaga Keuangan Syariah. Jakarta: Kencana Prenada Media Group

Soemitra, Andri. (2010) bank dan lembaga keuangan syariah. Jakarta: Kencana Prenada Media Group

Sri, Susilo, dkk. (2000), Bank dan lembaga keuangan lain. Jakarta:Salemba Empat

Subramanyam,Dkk.(2013), Analisa Laporan Keuangan. Jakarta:Salemba Empat

Suhardjono.(2003), Manajemen Pengkreditan Usaha Kecil dan Menengah. Jakarta: UPP AMP YKPN Susyanti, Jeni. (2016), Pengelolan Lembaga Keuangan Syariah. Malang: Empat Dua
Sutrisno.(2009), Manajemen Keuangan; Teori Konsep dan Aplikasi. Yogyakarta: Ekonisia

Sumadi, S., \& Ma'ruf, M. H. (2020). IMPLEMENTATION OF THE CONCEPT AND THEORY OF MANAGEMENT FUNCTIONS IN EFFORTS TO IMPROVE QUALITY. International Journal of Economics, Business and Accounting Research (IJEBAR), 4(02).

Umiyati, dan Leni.(2017), Faktor yang Mempengaruhi Pembiayaan pada Bank Umum Syariah Devisa di Indonesia. Jurnal Ekonomi dan Perbankan Syariah. Vol 5 No 1

Waluyo.(2014), Fiqih Muamalat. Yogyakarta: Gerbang Media Aksara

UU No 10 Tahun 1998 Tentang Pembiayaan UU No 21 Tahun 2008 Tentang Perbankan www.syariahmandiri.co.id 